\title{
The value of immunohistochemistry on paraffin wax embedded tissue sections in the differentiation of small lymphocytic and mantle cell lymphomas
}

\author{
N Singh, D H Wright
}

\begin{abstract}
Aims-To determine whether immunohistochemistry applied to paraffin wax embedded biopsy tissue can be used to distinguish between B-small lymphocytic lymphoma (B-SLL) and mantle cell lymphoma (MCL).

Methods-Formalin fixed, paraffin wax embedded tissue blocks of 12 cases of B-SLL and 12 cases of MCL were retrieved from the files of the Department of Pathology, Southampton University Hospitals Trust. Following antigen retrieval, where appropriate, sections were stained for CD3, CD5, CD20, CD23, CD43, Cyclin D, PGP9.5, and MIB1 using a streptavidin-biotin complex technique.

Results-CD20 stained the neoplastic cells of B-SLL and MCL, and CD3 labelled the reactive $T$ cells in these tumours. In B-SLL, the $T$ cells were generally dispersed among the tumour cells, whereas in MCL they often formed bands around tumour cell nodules. CD5 could be detected on $T$ cells, following antigen retrieval. The level of expression on $B$ cells of B-SLL and MCL was generally too low to allow detection in paraffin wax embedded tissues. CD23 stained B-SLL but not MCL. However, it could be detected in only five of the 12 cases of B-SLL. CD43 could be detected in most cases of B-SLL and MCL. It is not, therefore, of value in distinguishing between these tumours. It will, however, help in the differentiation of B-SLL and MCL from other low grade B cell lymphomas, such as follicle centre cell and marginal zone lymphomas. Cyclin D was expressed in all of the MCL but in none of the B-SLL. PGP9.5 showed reactivity in most cases of MCL and much weaker reactivity in B-SLL. The proliferation indexes of $M C L$ were generally higher than those of B-SLL, as measured by MIB1 labelling. Both tumours, however, showed a wide range of values and considerable overlap.
\end{abstract}

Conclusion-Staining for Cyclin D is the most reliable immunohistochemical means of differentiating between B-SLL and MCL. High levels of PGP9.5, expressed in MCL, may be related to the degradation of Cyclin $D$ by the ubiquitin pathway.

(F Clin Pathol 1997;50:16-21)

Keywords: B-small lymphocytic lymphoma; mantle cell lymphoma; Cyclin D.

Mantle cell lymphoma (MCL) ${ }^{12}$ has been widely accepted as the preferred term for the lymphoma previously designated as centrocytic lymphoma (Kiel classification), ${ }^{3}$ intermediately $^{4-6}$ or poorly differentiated lymphocytic (Rappaport), ${ }^{7}$ small cleaved follicular centre cell (Lukes and Collins), ${ }^{8}$ small cleaved cell (Working Formulation), ${ }^{9}$ and mantle zone lymphoma..$^{10} \mathrm{~A}$ proportion of MCL have blastic features and may mimic lymphoblastic lymphoma in routinely processed tissue sections. ${ }^{11}$ At the other end of the morphological spectrum, MCL may resemble small lymphocytic lymphoma (B-SLL/B-CLL), as the tumour cell nuclei in both of these lymphomas may be round or cleaved. ${ }^{2}$ It has been stated that the distinction between B-SLL and MCL "using morphological features alone is frequently challenging". ${ }^{12}$ This has also been our experience. Whereas there are well defined morphological characteristics that separate B-SLL and MCL, ${ }^{21}$ these may not be apparent in all biopsy specimens, depending on, amongst other factors, the size of the specimen and the quality of fixation. The distinction between these two entities is of importance, as MCL usually follows a more aggressive course $e^{413-15}$ and treatment needs to be modified accordingly. A number of studies have shown the value of flow cytometry ${ }^{12}$ or immunohistochemistry on frozen sections $s^{516}$ in separating these lymphomas. The pathologist with only a fixed, paraffin wax embedded biopsy specimen, however, does not have the option of using these techniques. We have, therefore, studied the discriminatory value of a panel of antibodies reactive in fixed, paraffin wax embedded 
Table 1 Clinical features

\begin{tabular}{|c|c|c|c|}
\hline Patient group & Age & $\operatorname{Sex}$ & Clinical presentation \\
\hline \multicolumn{4}{|c|}{ Small lymphocytic lymphoma (CLL) } \\
\hline & 58 & $M$ & Enlarged cervical lymph node \\
\hline & 71 & $\mathbf{M}$ & Enlarged cervical lymph node, known CLL \\
\hline & 72 & $\mathrm{~F}$ & Enlarged cervical lymph node \\
\hline & 73 & $\mathbf{M}$ & Enlarged axillary lymph node \\
\hline & 63 & $\mathrm{M}$ & $\begin{array}{l}\text { Enlarged cervical and supraclavicular lymph nodes, } \\
\text { known CLL }\end{array}$ \\
\hline & 77 & $\mathbf{M}$ & Enlarged submandibular lymph node \\
\hline & 73 & $\mathbf{M}$ & Enlarged cervical lymph node \\
\hline & 56 & $\mathbf{M}$ & Enlarged axillary lymph nodes \\
\hline & 89 & $\mathbf{M}$ & Lymphadenopathy \\
\hline & 60 & $\mathrm{~F}$ & Submandibular lymph node, known CLL \\
\hline & 68 & $\mathrm{~F}$ & Submandibular lymph node \\
\hline & 64 & $\mathrm{~F}$ & Known CLL, splenectomy \\
\hline \multicolumn{4}{|c|}{ Mantle zone lymphomas } \\
\hline & 46 & $\mathbf{M}$ & $\begin{array}{l}\text { Enlarged inguinal lymph node; previous mantle cell } \\
\text { lymphoma of stomach }\end{array}$ \\
\hline & 64 & $\mathbf{M}$ & Lymphadenopathy and splenomegaly \\
\hline & Unknown & F & Lymphadenopathy \\
\hline & 70 & $\mathrm{~F}$ & Lymphadenopathy and splenomegaly \\
\hline & 50 & M & Lymphadenopathy \\
\hline & 83 & F & Lymphomatous polyposis \\
\hline & 69 & $\mathbf{M}$ & Generalised lymphadenopathy \\
\hline & Unknown & $\mathbf{M}$ & Lymphadenopathy \\
\hline & 76 & $\mathrm{~F}$ & Inguinal lymphadenopathy, splenomegaly \\
\hline & 43 & $\mathrm{M}$ & Parotid gland and small intestine \\
\hline & 40 & $\mathbf{M}$ & Lymphadenopathy \\
\hline & 63 & F & Supraclavicular lymphadenopathy \\
\hline
\end{tabular}

tissues for the identification and separation of B-SLL and MCL.

\section{Methods}

Using standard morphological criteria, 12 cases of B-SLL and 12 cases of MCL were selected from the files of the Department of Pathology, Southampton University Hospitals Trust. Some of these cases had been biopsied locally and others had been referred from elsewhere. Brief clinical details of these patients are given in table 1 . All biopsy specimens had been fixed in formol saline. For morphological evaluation, all biopsy specimens were stained with haematoxlyin and eosin, Giemsa stain, periodic acid Schiff, and for reticulin using the Gordon and Sweet method.

Immunohistochemistry was done using a streptavidin-biotin-complex technique, after antigen retrieval when appropriate. Sections were incubated with the primary antiserum at $4^{\circ} \mathrm{C}$ overnight. Details of section pretreatment, antibodies used and their specificities are given in table 2. Microwave pretreatment was done in 0.01 sodium citrate buffer, $\mathrm{pH} 6.0$, at $560 \mathrm{~W}$

Table 2 Antibodies tested

\begin{tabular}{|c|c|c|c|c|}
\hline $\begin{array}{l}\text { Antibody/ } \\
\text { CD group }\end{array}$ & Type & Source & Pretreatment & Specificity \\
\hline CD3 & $P$ & Dako & Trypsin & Pan T cell \\
\hline CD5 & M & Dr K Gatter & Microwave & T cells, some B cells \\
\hline CD20 (L26) & $\mathbf{M}$ & Dako & - & Mature B cells \\
\hline CD23 & $M$ & Dako & Microwave & $\begin{array}{l}\text { Low affinity IgE receptor; B } \\
\text { cells, T cells, monocytes, } \\
\text { dendritic cells }\end{array}$ \\
\hline CD43 (MT1) & $\mathbf{M}$ & Novocastra & Microwave & $\begin{array}{l}\mathrm{T} \text { cells, some B cells, } \\
\text { myelomonocytic cells }\end{array}$ \\
\hline Cyclin D & $\mathbf{P}$ & Prof N Harris & Microwave & Cyclin D \\
\hline PGP9.5 & $\mathbf{P}$ & Prof R Thompson & Microwave & $\begin{array}{l}\text { Ubiquitin, } \\
\text { carboxyl-terminal hydrolase } \\
\text { isoenzyme L1 }\end{array}$ \\
\hline MIB1 & $\mathbf{M}$ & The Binding Site & Microwave & $\begin{array}{l}\text { Ki67 antigen (expressed in } \\
\text { nuclei of cells in cycle) }\end{array}$ \\
\hline
\end{tabular}

Source: Dako, High Wycombe, UK; Novocastra, Newcastle, UK; The Binding Site, Birmingham, UK; Dr K Gatter, Oxford, UK; Professor N Harris, Boston, USA; Professor R Thompson, Southampton, UK.

$\mathrm{P}=$ rabbit polyclonal; $M=$ mouse monoclonal

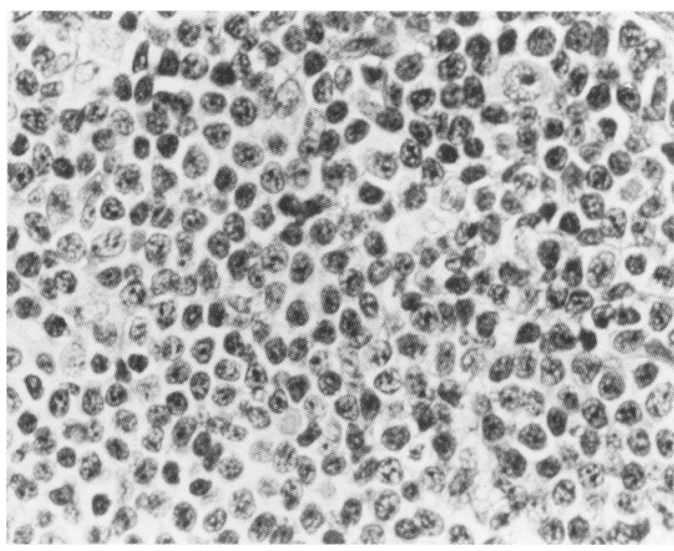

Figure $1 \quad B-S L L$ showing typical rounded cells. There is a single para-immunoblast in the top right-hand corner (original magnification $\times 480$ ).

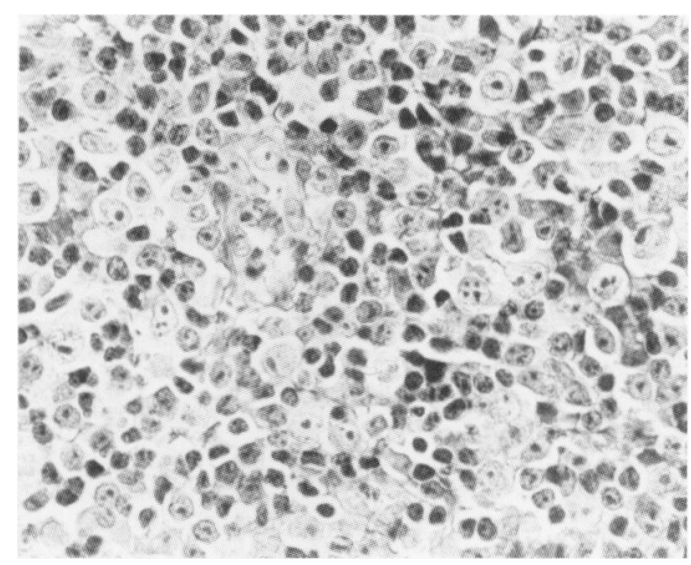

Figure 2 B-SLL showing large numbers of pro-lymphocytes and para-immunoblasts in a proliferation centre (original magnification $\times 480$ ).

for 25 minutes. Sections were evaluated by both authors. Labelling indexes were determined by one author (NS) on sections labelled with MIB1 by counting 10 high power fields using an eyepiece graticule.

\section{Results}

The 12 cases of B-SLL showed the characteristic histological features of this lymphoma. Para-immunoblasts were usually evident, either singly (fig 1) or aggregated into 'proliferation centres' (fig 2), although in a few cases they were absent from much of the tumour (fig 3). In two cases, the para-immunoblasts formed the majority of the tumour cells, consistent with the 'tumour forming subtype' of B-SLL." The MCL cases showed a range of morphologies from uniform small lymphoid cells (fig 4) to more pleomorphic tumours, with irregular nuclei (fig 5). Most cases showed a vaguely nodular growth pattern. Naked germinal centres were present at the centre of occasional nodules, giving the appearance of a mantle zone lymphoma. Characteristic histiocytes, with eosinophilic cytoplasm, were seen in all cases (fig 4).

The immunohistochemical findings are shown in table 3. Staining for CD3 and CD20 did not discriminate between tumour cells of B-SLL and MCL, but did identify different distributions of the reactive $T$ cells in the two tumour types. In B-SLL, reactive $T$ cells were irregularly scattered amongst the tumour cells (fig 6), whereas in MCL they often appeared as 


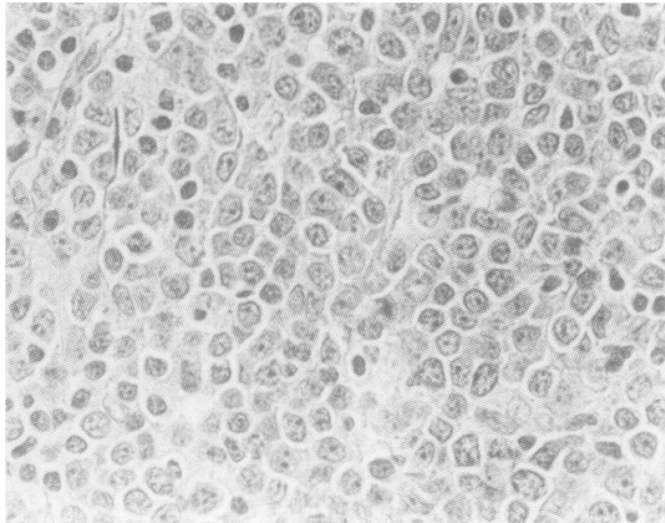

Figure 3 B-SLL showing more angulated nuclei than those seen in fig 1. No para-immunoblasts are seen in this field, making morphological distinction from $M C L$ difficult (original magnification $\times 480$ ).

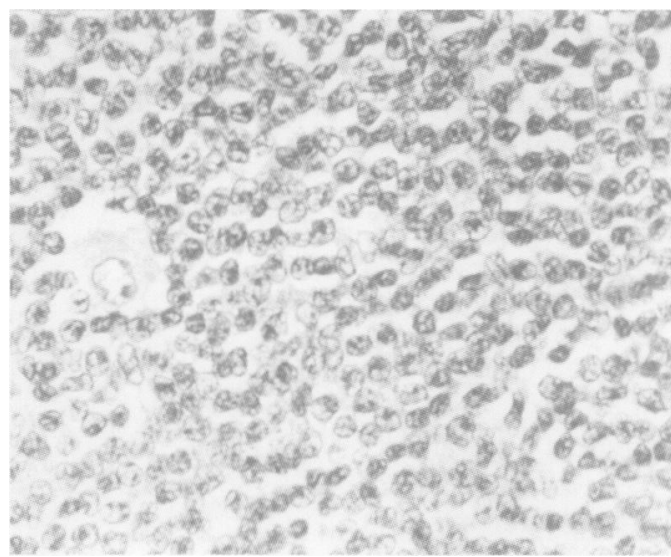

Figure 4 MCL showing rounded tumour cells similar to those seen in the B-SLL illustrated in fig 1 . There are no para-immunoblasts. The large histiocyte present, on the left side of the photograph, is characteristic of $M C L$ (original magnification $\times 480$ ).

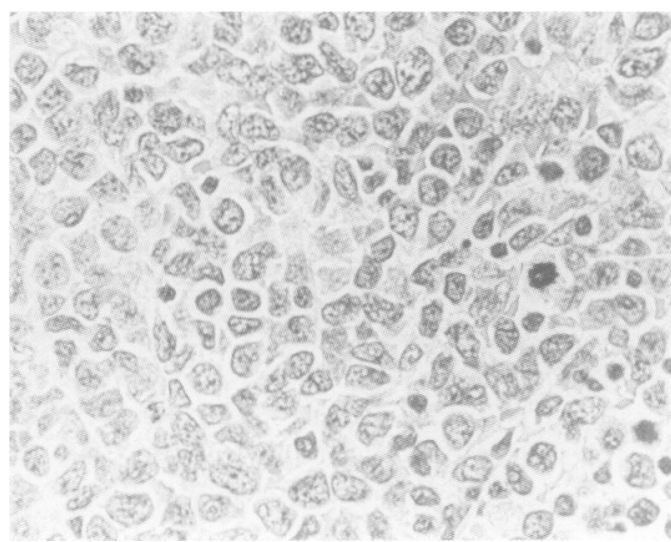

Figure 5 Typical MCL showing angulated nuclei without para-immunoblasts (original magnification $\times 480$ ).

Table 3 Immunohistochemical findings

\begin{tabular}{|c|c|c|c|}
\hline \multirow[b]{2}{*}{$\begin{array}{l}\text { Antibody/ } \\
C D \text { group }\end{array}$} & \multicolumn{2}{|c|}{ Reactivity of tumour cells } & \multirow[b]{2}{*}{ Comments } \\
\hline & $\begin{array}{l}B-S L L \\
(12 \text { cases })\end{array}$ & $\begin{array}{l}M C L \\
\text { (12 cases) }\end{array}$ & \\
\hline CD3 & 0 & 0 & Reactive $\mathrm{T}$ cells positive \\
\hline $\mathrm{CD} 20$ & 12 & 12 & \\
\hline CD5 & 3 & 2 & $\begin{array}{l}\text { Weak reactivity of tumour cells; strong } \\
\text { reactivity of T cells }\end{array}$ \\
\hline $\mathrm{CD} 23$ & 5 & 0 & $\begin{array}{l}\text { Weak reactivity; dendritic reticulum cells } \\
\text { positive }\end{array}$ \\
\hline CD43 & 10 & 12 & Variable reactivity \\
\hline Cyclin D & 0 & 12 & \\
\hline PGP9.5 & 7 & 11 & Stronger reactivity of MCL than B-SLL \\
\hline MIB1 & $\begin{array}{l}8-71 \\
(\text { mean } 22)\end{array}$ & $\begin{array}{l}7-90 \\
(\text { mean } 31)\end{array}$ & Proliferation indexes \\
\hline
\end{tabular}

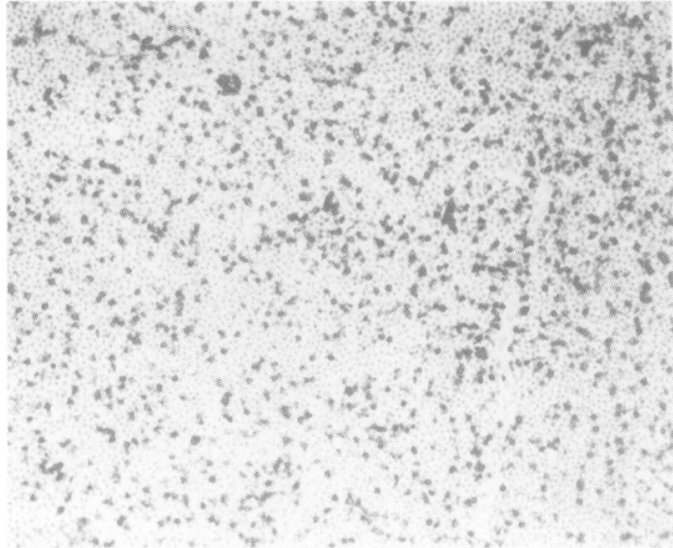

Figure 6 B-SLL showing uniform scattering of $T$ cells throughout the tumour. Immunoperoxidase CD3 (original magnification $\times 120$ ).

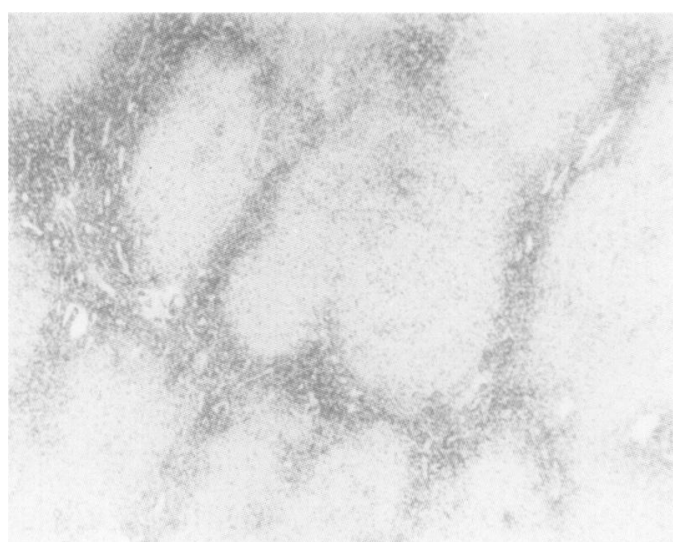

Figure 7 MCL showing distribution of $T$ cells in bands around tumour cell nodules. Immunoperoxidase CD3

(original magnification $\times 30$ ).

defined bands of cells between the tumour cell nodules (figs 7 and 8). CD5 is expressed by both B-SLL and MCL cells, but in the paraffin wax embedded tissues used in the present study the expression was detected in only a minority of cases and was weak. This contrasted with the strong expression on reactive $\mathrm{T}$ cells. CD23 is expressed on B-SLL but not MCL cells. However, in the present study, expression was seen in only five cases of B-SLL, the staining being more pronounced in para-immunoblasts than small lymphocytes (fig 9). No cases of MCL stained for CD23, although labelling of a dispersed network of dendritic reticulum cells was seen in these tumours (fig 10). Cyclin D was expressed by all of the MCL in this series but by none of the B-SLL. The reactivity was seen in the nuclei of the tumour cells and varied in any one tumour from negative to strong (figs 11 and 12). All but one MCL strongly expressed PGP9.5 (fig 13). Seven of the B-SLL stained positively with this antibody, but this was usually much weaker than that seen in MCL. The labelling index with MIB1 varied widely in both tumours, the mean index being slightly higher for MCL than for B-SLL (figs 14 and 15).

We found no difference in the morphology or immunoreactivity of MCL occurring in lymph nodes and the two cases that had intestinal tumours. 


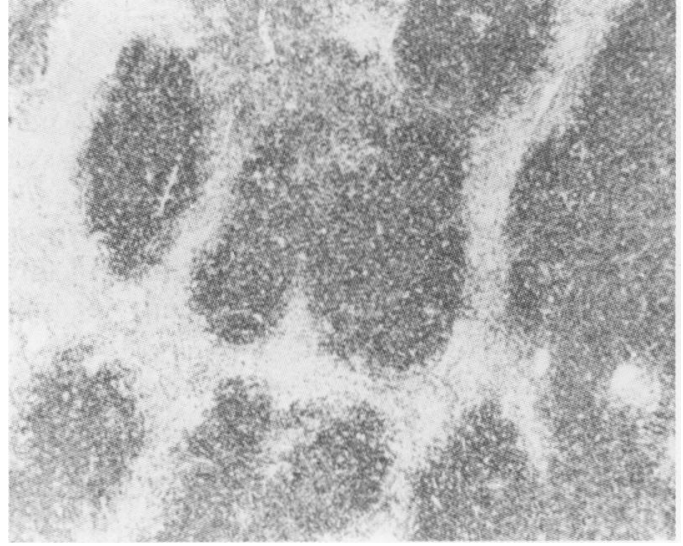

Figure 8 MCL stained with L26 (CD20) showing the same field as that illustrated in fig 7. Immunoperoxidase (original magnification $\times 30$ ).

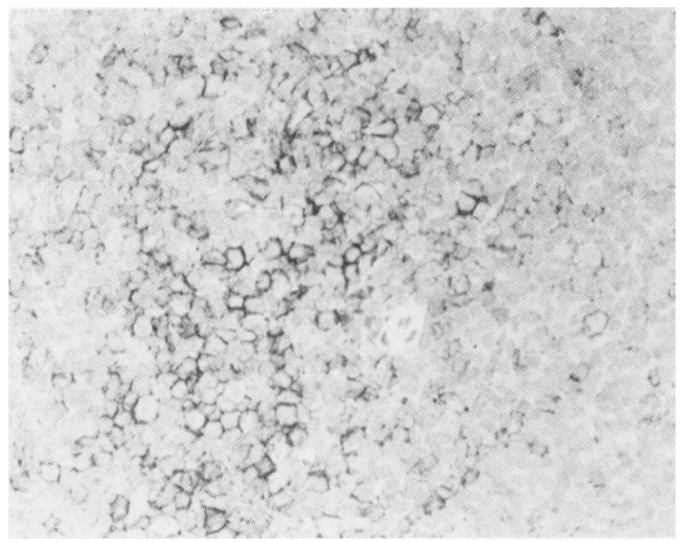

Figure $9 B-S L L$ stained for CD23. Expression is strongest on para-immunoblasts. Immunoperoxidase (original magnification $\times 300$ ).

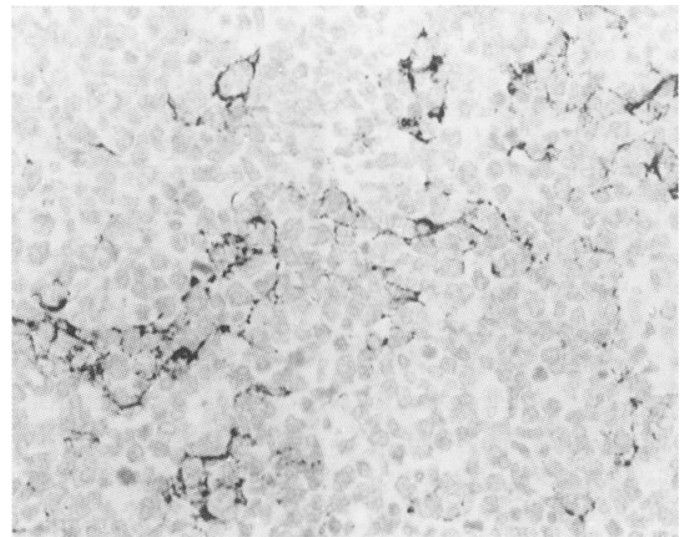

Figure $10 \quad M C L$ stained for $C D 23$, showing staining of dendritic reticulum cells. The tumour cells are negative.

Immunoperoxidase (original magnification $\times 300$ ).

\section{Discussion}

Mantle cell lymphoma has been recognised as a distinct entity in recent years. ${ }^{12}$ The Kiel group originally thought that it was of follicle centre cell origin, hence their use of the term 'centrocytic lymphoma'. ${ }^{3}$ In the Working Formulation it was designated diffuse, small cleaved cell lymphoma and shown to have a prognosis intermediate between low and high grade lymphomas. ${ }^{9}$ Because of its more aggressive behaviour, it should be separated from low grade lymphomas and possibly treated differently. Morphological criteria on which this separation can be based are well defined but, in our experience, the separation of B-SLL from

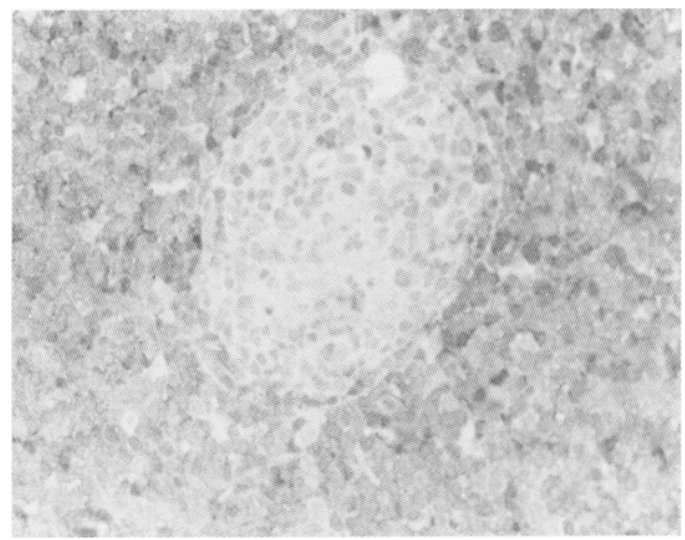

Figure 11 MCL stained to show Cyclin D. This tumour has a mantle zone distribution. Note the negative reaction of the germinal centre. Immunoperoxidase (original magnification $\times 300$ ).

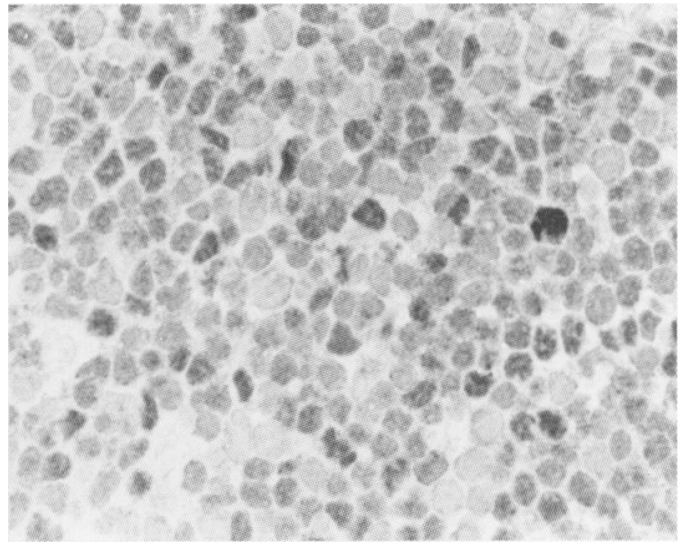

Figure 12 Mantle cell lymphoma stained to show Cyclin D. Note the variable staining of tumour cell nuclei.
Immunoperoxidase (original magnification $\times 480$ ).

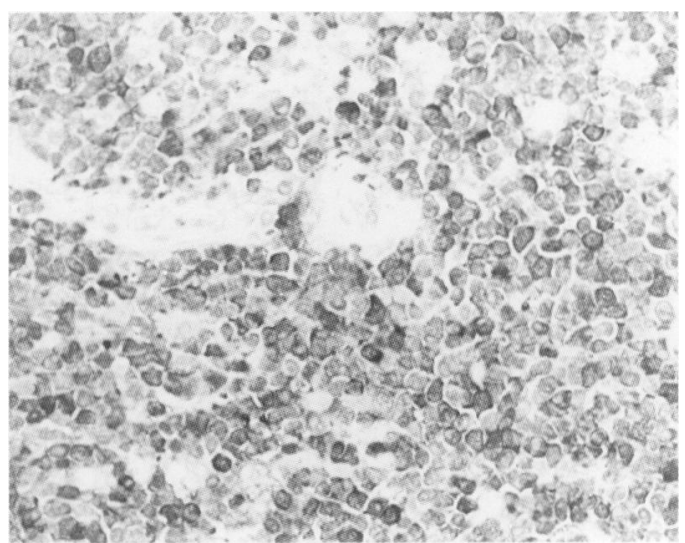

Figure 13 MCL stained for PGP 9.5. Note strong, but variable, staining of tumour cell nuclei and cytoplasm. Immunoperoxidase (original magnification $\times 300$ ).

MCL can be difficult. The tumour cells of B-SLL are typically round lymphocytes, whereas the cells of MCL are angulated or cleaved. However, the tumour cells of B-SLL may show angulated nuclei and those of MCL may be rounded. The presence of paraimmunoblasts is probably the most reliable way of separating B-SLL from MCL but they are not always easy to find and they may be mimicked by residual centroblasts, histiocytes and dendritic reticulum cell nuclei, more so in haematoxylin and eosin than in Giemsa stained preparations. It was for this reason that we looked at the feasibility of using immunohisto- 


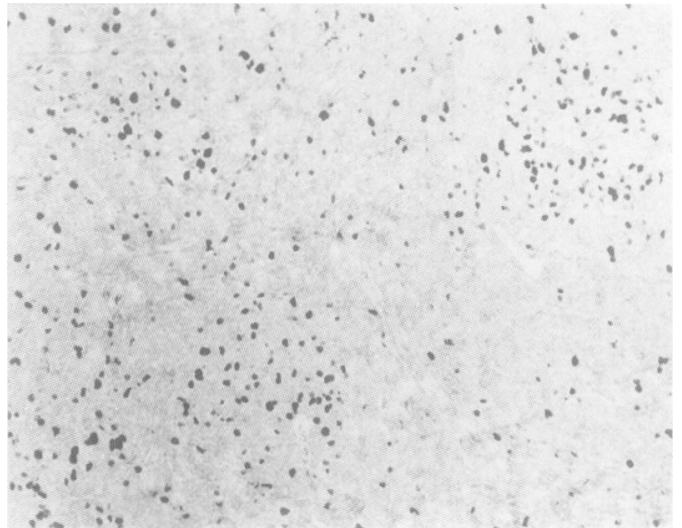

Figure 14 B-SLL stained for the proliferation marker MIB1. The clustering of labelled nuclei corresponds to proliferation centres. Immunoperoxidase (original magnification $\times 120$ ).

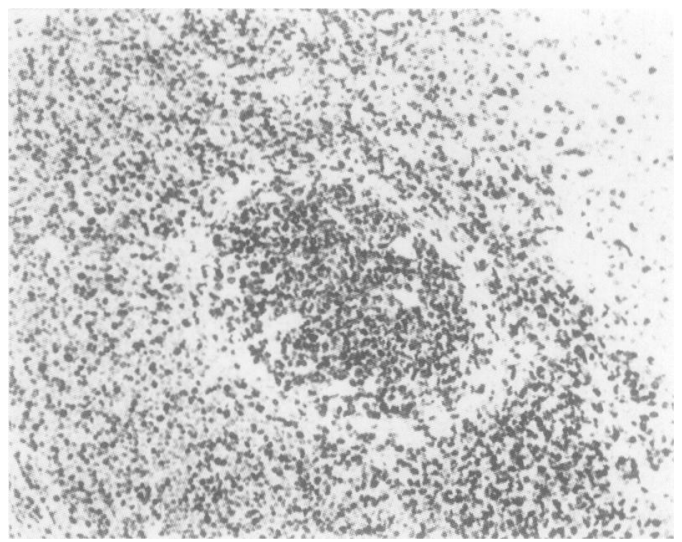

Figure 15 MCL with mantle zone growth pattern stained for the proliferation marker MIB1. There is heavy labelling of the reactive germinal centre, surrounded by $M C L$ showing a high labelling index. The residual T-zone (top right) shows a low labelling index. Immunoperoxidase (original magnification $\times 120$ ).

chemical markers, applicable to paraffin wax embedded tissues, to make this distinction.

CD20 is expressed on mature B cells and CD3 is expressed on $T$ cells. These two antibodies would not, therefore, be expected to distinguish between B-SLL and MCL at the cellular level. They do, however, highlight the architectural differences between these two neoplasms. B-SLL usually shows a scattering of $T$ cells throughout the tumour, whereas in MCL they form bands between the nodules of lymphoma cells. CD5 is expressed on the cells of both B-SLL and MCL and may be used to separate them from follicle centre cell and marginal zone (MALT) lymphomas on frozen sections. ${ }^{17}$ Antigen retrieval techniques permit the detection of CD5 in paraffin wax embedded tissue ${ }^{18}$ but, as the present study shows, the level of expression of this antigen on $B$ cells precludes reliable identification, in contrast to $\mathrm{T}$ cells which are labelled. It remains to be seen whether signal enhancement techniques ${ }^{19}$ will overcome this problem. In contrast, CD43 can be demonstrated on the cells of B-SLL and MCL, in almost all cases, following microwave antigen retrieval. This antigen will not discriminate between B-SLL and MCL but will separate them from follicle centre cell lymphomas and marginal zone lymphomas. ${ }^{20}$

CD23, a low affinity receptor for IgE, is expressed on the cells of B-SLL but not on those of MCL and may be used with frozen section immunohistochemistry ${ }^{17}$ or flow cytometry $^{12}$ to separate these two neoplasms. In this study, we found expression of CD23 on only five of 12 cases of B-SLL, precluding its use as a routine marker in paraffin wax sections. Again, it remains to be seen whether other methods of antigen retrieval ${ }^{21}$ or signal enhancement techniques will overcome this problem.

Mantle cell lymphoma is characterised by a translocation between the Cyclin D1 gene on chromosome 11 and the immunoglobulin heavy chain gene on chromosome $14^{22-25}$ in about $70 \%$ of cases. ${ }^{26}$ This translocation results in the overexpression of Cyclin D1 in the nuclei of the tumour cells of MCL, ${ }^{27}$ which is also seen in cases of MCL without detectable molecular evidence of $t(11 ; 14) .{ }^{26}{ }^{27}$ With one exception, expression of Cyclin D1 has not been seen in B-SLL. It has also been recorded rarely in hairy cell leukaemia and plasmacytoma. ${ }^{28}$ Our studies confirm Cyclin D1 as the most reliable marker for the distinction between B-SLL and MCL. A monoclonal antibody directed against Cyclin D1 is now available $^{27}$ and, in our experience, works as well as the polyclonal antibody used in this study.

Antibodies directed against protein gene product 9.5 (PGP9.5) detect the $\mathrm{L} 1$ isoenzyme of ubiquitin carboxyl-terminal hydrolase ${ }^{30}$ and are used as markers of neuronal differentiation. Langlois et al discovered that, after microwave heating in citrate buffer, lymphoid follicles also stained strongly with this antibody. ${ }^{31}$ These authors subsequently tested a range of lymphomas using this technique but found no relation between type or grade of lymphoma and staining of tumour cells. ${ }^{32}$ Western blots carried out on brain and tonsil extracts, using the polyclonal antibody, showed a band of greater molecular weight than PGP9.5 in the tonsil extract. Langlois et $a l^{22}$ concluded that this additional band might represent other isoenzymes of ubiquitin carboxyl-terminal hydrolase that can be found in other tissues, including lymphoma cell lines. The one example of MCL (centrocytic lymphoma) included in their study showed strong staining with PGP9.5. In our study we found strong staining for PGP9.5 in 11 of the 12 cases of MCL. Seven of the 12 cases of B-SLL also showed reactivity but generally with much weaker staining. Cyclin is degraded by the ubiquitin pathway ${ }^{33}$ and it may be that the stronger expression of PGP9.5 in MCL is related to the overexpression of Cyclin D1 in these tumours. From a practical point of view, it is unlikely that polyclonal antibodies directed against PGP9.5 will be of value in the identification of MCL. However, antibodies directed against other isoenzymes of ubiquitin carboxyl-terminal hydrolase might be worthy of further investigation.

We are indebted to Dr Kevin Gatter, Professor Nancy Harris and Professor Rodney Thompson for the gift of antibodies. We thank Lorraine West and Julie Williams for performing the immunohistochemistry and Julie Foster for typing the manuscript.

1 Banks PM, Chan J, Cleary ML, Delsol G, De Wolf-Peeters $\mathrm{C}$, Gatter $\mathrm{K}$, et al. Mantle cell lymphoma: A proposal for 
unification of morphologic, immunologic and molecular data. Am f Surg Pathol 1992;16:637-40.

2 Harris NL, Jaffe ES, Stein H, Banks PM, Chan KC, Cleary $\mathrm{ML}$, et al. A revised European-American classification of lymphoid neoplasms: A proposal from the International Lymphoma Study Group. Blood 1994;84:1361-92.

3 Gerard-Marchant $R$, Hamlin I, Lennert $K$, Rilke $F$, Stansfeld AG, van Unnik JAM. Classification of nonHodgkin's lymphomas. Lancet 1974;ii:406.

4 Perry D, Bast M, Armitage J, Weisenburger D. Diffuse, intermediate, lymphocytic lymphoma: A clinico-pathologic study and comparison with small lymphocytic lymphoma study and comparison with small lymphocytic lymphoma
and diffuse, small cleaved cell lymphoma. Cancer 1990;66:

5 Lardelli P, Bookman M, Sundeen J, Longo D, Jaffe E. Lymphocytic lymphoma of intermediate differentiation: Morphologic and immunophenotypic spectrum and clinical correlations. Am ₹ Surg Pathol 1990;14:752-63.

6 Weisenburger D, Linder J, Daley H, Armitage J. Intermediate lymphocytic lymphoma: An immunohistologic study with comparison to other lymphocytic lymphomas. Hum Pathol 1987;18:781-90.

7 Rappaport H. Tumors of the hematopoietic system. In: Atlas of tumor pathology. Section 3. Fascicle 8. Washington DC
. of tumor pathology. Section 3. Fascicle 8. Washing
US Armed Forces Institute of Pathology, 1966.

8 Lukes RJ, Collins RD. Immunological characterisation of human malignant lymphomas. Cancer 1974;34:1488-503.

9 Non-Hodgkin's lymphoma. Pathologic classification project. National Cancer Institute sponsored study of classifications of non-Hodgkin's lymphomas: Summary and description of a working formulation for clinical usage. Cancer 1982;49:2112-35.

10 Weisenburger DD, Kim H, Rappaport H. Mantle zone lymphoma: A follicular variant of intermediate lymphocytic lymphoma: A follicular variant of interme

11 Lennert K, Feller AC. Histopathology of non-Hodgkin's lymphomas (based on the updated Kiel classification). 2nd edn. Berlin: Springer Verlag, 1992:101

12 Kilo MN, Dorfman DM. The utility of flow cytometric immunophenotypic analysis in the distinction of small lymphocytic lymphoma/chronic lymphocytic leukemia from mantle cell lymphoma. Am 7 Clin Pathol 1996;105:451-7.

$13 \mathrm{Jaffe}$ ES, Bookman MA, Longo DL. Lymphocytic lymphoma of intermediate differentiation-Mantle zone lymphoma: A distinct subtype of B-cell lymphoma. Hum Pathol 1987;18:877-80.

14 Berger F, Felman P, Sonet A, Salles G, Bastion Y, Bryon PA, et al. Non-follicular, small, B-cell lymphomas: A heterogeneous group of patients with distinct clinical features and outcome. Blood 1994;83:2829-35.

15 Pittaluga S, Wlodarska I, Stul MS, Thomas J, Verhoef G, Cassiman J, et al. Mantle cell lymphoma: A clinicopathological study of 55 cases. Histopathology 1995;26:1724.

16 Strickler JG, Medeiros J, Copenhaver CM, Weiss LM, Warnke RA. Intermediate lymphocytic lymphoma: An
immunophenotypic study with comparison to small immunophenotypic study with comparison to small lymphocytic lymphoma and diffuse,

17 Zukerberg LR, Medeiros LJL, Ferry JA, Harris NL. Diffuse, low-grade B-cell lymphomas. Four clinically distinc subtypes defined by a combination of morphologic and immunophenotypic features. Am f Clin Pathol 1993;100: 373-85.
18 Cuevas EC, Bateman AC, Wilkins BS, Johnson PA, Williams JH, Lee AHS, et al. Microwave antigen retrieval in immunocytochemistry: A study of 80 antibodies. $f$ Clin Pathol 1994;47:448-52.

19 Merz H, Malisius S, Mannweiler R, Zhou W, Hartman N, Orscheschek $\mathrm{K}$, et al. Methods in laboratory investigation. ImmunoMax. A maximised immunohistochemical method for the retrieval and enhancement of hidden antigens. $L a b$ Invest 1995; 73:149-56.

20 Treasure J, Lane A, Jones DB, Wright DH. CD43 expression in B-cell lymphoma. F Clin Pathol 1992;45: 1018-22.

21 Morgan JM, Navabi H, Schmid KW, Jasani B. Possible role of tissue-bound calcium ions in citrate-mediated hightemperature antigen retrieval. $\mathcal{F}$ Pathol 1994;174:301-7.

22 Weisenburger DD, Sanger WG, Armitage JO, Purtilo DT. Intermediate lymphocytic lymphoma: Immunophenotypic and cytogenetic findings. Blood 1987;69:1617-21.

23 Frizzera G, Sakurai M, Notohara K, Konishi H. t(11;14) (q13;q32) in B-cell lymphomas (intermediately differentiated lymphocytic and follicular): A report of 4 cases. $A m \mathcal{F}$ Clin Pathol 1991;95:684-91.

24 Vandenberghe $E$, de Wolf-Peeters $C$, van den Oord J, Wlodarska I, Delabie J, Stul M, et al. Translocation (11;14): A cytogenetic anomaly associated with B-cell lymphomas of non-follicle centre cell lineage. $\mathcal{F}$ Pathol 1991;163:13-18.

25 Leroux D, Le Marc'Hadour F, Gressin R, Jacob MC, Keddari E, Monteil M, et al. Non-Hodgkin's lymphomas with $t(11 ; 14)$ (q13;q32): A subset of mantle zone-intermediate lymphocytic lymphoma? Br $\mathcal{F}$ Haematol 1991;77:346-53.

26 Swerdlow SH, Yang W-I, Zukerberg LR, Harris NL, Arnold A, Williams ME. Expression of Cyclin D1 protein in centrocytic/mantle cell lymphomas with, and without, rearrangement of the BCL-1/Cyclin D1 gene. Hum Pathol 1995;26:999-1004.

27 Ott MM, Helbing A, Ott G, Bartek J, Fischer L, Dürr A, et al. bcl-1 rearrangement and Cyclin D1 protein expression in mantle cell lymphoma. F Pathol 1996;179:238-42.

28 Yang W-I, Zukerberg LR, Motokura T, Arnold A, Harris NL. Cyclin D1 (Bcl-1, PRAD1) protein expression in lowgrade B-cell lymphomas and reactive hyperplasia. $A m \mathcal{F}$ Pathol 1994;145:86-96.

29 Zukerberg LR, Yang W-I, Arnold A, Harris NL. Cyclin D1 expression in non-Hodgkin's lymphomas. Detection by immunohistochemistry. Am f Clin Pathol 1995;103:756-60.

30 Wilkinson KD, Lee K, Deshpande S, Duerksen-Hughes $\mathrm{P}$ Boss JM, Pohl J. The neuron-specific protein PGP9.5 is a ubiquitin carboxyl-terminal hydrolase. Science 1989;246: $670-3$.

31 Langlois NEI, King G, Herriot R, Thompson WD. Non-enzymatic retrieval of antigen permits staining of follicle centre cells by the rabbit polyclonal antibody to protein gene product 9.5. F Pathol 1994;173:249-53.

32 Langlois NEI, King G, Herriot R, Thompson WD. An evaluation of the staining of lymphomas and normal tissues by the rabbit polyclonal antibody to protein gene product 9.5, following non-enzymatic retrieval of antigen. $\mathcal{f}$ Pathol 1995;175:433-9.

33 Glotzer M, Murray AW, Kirschner MW. Cyclin is degraded by the ubiquitin pathway. Nature 1991;349:132-8. 